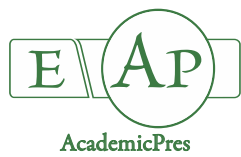

\title{
Feasibility Study on Reducing Lead and Cadmium Absorption by Alfalfa (Medicago scutellata L.) in a Contaminated Soil Using Nano-Activated Carbon and Natural Based Nano-Zeolite
}

\author{
Tahereh HASANABADI ${ }^{1}$, Shahram LACK ${ }^{2}$, Adel MODHEJ ${ }^{3}$, \\ Hossein GHAFURIAN ${ }^{4}$, Mojtaba ALAVIFAZEL ${ }^{2}$, M. Reza ARDAKANI ${ }^{5 *}$ \\ ${ }^{1}$ Young Researchers and Elites Club, Tehran North Branch, Islamic Azad University, Tehran, Iran; t.hasanabadi@gmail.com \\ 2Islamic Azad University,Department of Agronomy, Ahvaz Branch, Ahvaz,Iran; sh.lack@yahoo.com; mojtaba_alavifazel@yahoo.com \\ ${ }^{3}$ Islamic Azad University, Department of Agronomy and Plant Breeding, Shoushtar Branch, Shoushtar, Iran; adelmodhej2006@yahoo.com \\ ${ }^{4}$ Islamic Azad University, Department of Environmental Science, North Tehran Branch, Tehran, Iran; ghaforian25@yahoo.com \\ ${ }^{5}$ Islamic Azad University, Department of Agronomy and Plant Breeding, Karaj Branch, Karaj, \\ Iran;mreza.ardakani@gmail.com (*corresponding author)
}

\begin{abstract}
The first risk posed by heavy metal pollution in an ecosystem is metal accumulation in the biomass of growing plants, which has harmful effects on human health. Natural-based nanoparticles are efficient in remediating environmental pollutants because they have a high surface/volume ratio, high chemical activity and produce no harmful side-products. The present study investigates the capacity of natural-based nano-porous adsorbents for reducing the availability of heavy metals to annual alfalfa (Medicago scutellata L.) roots and keeps them in soil. In a factorial experiment based on a randomized design (with four replications), three nano-adsorbents (nano-activated carbon, natural nano-zeolite and modified nano-zeolite) and two heavy metals (lead and cadmium) have been tested. The results demonstrated that applying the highest rate of activated carbon and modified nano-zeolite reduced shoot $\mathrm{Pb}$ content by $34 \%$ and $33.2 \%$, and shoot $\mathrm{Cd}$ content by $35.5 \%$ and $46.7 \%$, respectively, compared with the adsorbent-free control.
\end{abstract}

Keywords: activated carbon; alfalfa; heavy metals; nano-porous adsorbent

\section{Introduction}

There are several methods for removing environmental pollutants. Using nano particles is one of the most novel ones. Heavy metals and agrochemicals are introduced into the environment on a large scale through natural sources and human activities. The anthropogenic input of these materials in the environment is far higher than that introduced by natural processes; resulting in the accumulation of heavy metals in the environment (Samarbakhsh et al., 2009; Hoseinzade et al., 2016). Presence heavy metals in soils can be attributed to various environmental variables which include, but not limited to soil properties, parent material and human contribution such as irrigation and farming (Hu et al., 2014).

In recent years, heavy metals pollution in pastures has caused environmental problems. Forage crops are the most important source of livestock food production, with legumes being particularly important. The persistence and bioaccumulation of heavy metals in the tissues of organisms enable them to move up the food chain. This has triggered research on the patterns of heavy metal accumulation and distribution in forage crops in order to ensure consumer health.

Annual alfalfas, as legume forage crops, are a suitable choice for heavy metal accumulation studies because of their palatability, high forage yield, and high content of protein, vitamins, calcium and nitrogen. Annual alfalfas have a higher forage quality, nutrient content and energy compared with many other forage crops (Cocks et al., 1992). Medicago scutellata L. is one of the species of annual alfalfas with good quality and yield in Iran. Quality is an important factor for comparing and evaluating the value of crop plants, especially in the case of forage crops.

Today, using nanotechnology to remove pollutants once they have entered the environment has become a more commonly used method. Compared with physico-chemical 
1186

and biological approaches, it is easier and more cost effective to apply (Tratnyek and Johnson, 2006). A range of different adsorbent types are now available with pores at the nano scale or larger. What make nano adsorbents different from other types of adsorbents are pore stability and uniformity, high specific surface area, adjustable pore size, very low toxicity, high stability, environmental adaptability and biodegradation ability (Chen et al., 2010). Different types of zeolites and activated carbon are examples of micropore adsorbents; Also Several adsorbents such as zeolite, silica, and activated carbon could be used in the water treatment. Zeolite as a kind of adsorbent material has lots of advantages, such as wide range of sources of raw materials, being cheap and having good adsorption effect, is widely used as adsorbents, ion exchangers and catalysts which could also be used for drying gases, purification and sewage treatment (Ok et al., 2007).

Activated carbon is still the most commonly used adsorbent for remediating environmental pollution because of its high specific surface area and high purity rate. Adsorption is the most suitable technique for removing pigmented pollutants and recycling industrial sewage (Tsui et al., 2011). Another advantage of activated carbon is that it is cost effective for developing countries to produce from cheap and easily available raw materials. Numerous studies have tested the production of activated carbon from various organic materials. Activated carbon may be produced from groundnut (Song, 2012), industrial wastes (Kadirvelu, 2005) and bamboo wastes (Ahmad and Hameed, 2010). In all of these studies, activated carbon efficiently removed pollutants. Some studies indicate that natural zeolites such as clinoptilolite can absorb volatile organic compounds. Clinoptilolite mines are present in several regions Iran, making it an easily accessible adsorbent. Application of zeolites can reduce significantly the availability of $\mathrm{Cd}, \mathrm{Pb}$ and $\mathrm{Zn}$ in soil, through the adsorption process (Argiri et al., 2013; Putwattana et al., 2015)

Zeolites have a tetrahedral molecular geometry with four oxygen atoms orbiting a silicon atom; they have pores and channels measuring 3-10 angstrom. This structure gives zeolites cation exchange capacity of $2.16-4.73 \mathrm{meq} / \mathrm{g}$ (Kayabali and Kezer, 1998; Kocaoba et al., 2007). These features make zeolites suitable adsorbents for the removal of heavy metals. Panuccio et al. (2009) used zeolite to successfully remove low concentrations of cadmium from the aquatic environment. Wingenfelder et al. (2005) tested the effect of natural zeolite from Slovakia and the modified form on cadmium and other heavy metals removal. The results showed that natural zeolite had low capacity for cadmium adsorption, but efficiently adsorbed other heavy metals such as. In contrast, the modified form had high capacity for cadmium adsorption. A range of studies are available on the effect of different treatments for activating and improving the beneficial characteristics (adsorption efficiency) of zeolites (Benkli et al., 2005; Ghobadi et al., 2008). Panneerselvam et al. (2008) for example treated zeolite with phosphoric acid which enhanced its capacity for copper adsorption. Accordingly treating zeolites with acids is a key method for improving zeolite adsorption efficiency (Ghobadi et al., 2008).The fact that each group of zeolites responds differently to chemical treatments calls for determining the effective parameters and optimum conditions to obtain the best adsorption efficiency.

One of the most important applications of nanotechnology is the remediation of chemical pollutants in soil, water and air. This technique enables removing small sized pollutants $<200 \mathrm{~nm}$ in water resources and $<20 \mathrm{~nm}$ in air. The present experiment studies the effect of chemical treatment on the zeolite adsorption rate, and consequently examines the effect of nanopores in natural/modified zeolite and activated carbon on cadmium and lead absorption by Medicago scutellata $\mathrm{L}$.

\section{Materials and Methods}

Three experiments were conducted under greenhouse conditions in the form of a randomized design with three replications in 2016. Soil samples were initially analyzed in the laboratory to make sure they were lead and cadmium free. Then, soil lumps were ground and passed through a 4 $\mathrm{mm}$ sieve. The soil was polluted with the pollutants at rates higher than the allowed limit. The polluted pots were kept for 30 days to fix the chemical condition of the soil and reach a uniform soil mixture. Then, these treatments were applied to the pots, and the seeds of Medicago scutellata L. were cultivated. To evaluate the effect of treatments on the plant, sampling was conducted at the beginning of the flowering stage. At this time, the whole plant was harvested, washed with deionized water and dried at $70{ }^{\circ} \mathrm{C}$ in an oven. This was followed by plant analysis and measurement of heavy metals in plant tissue.

\section{The first experiment (natural nano zeolite)}

The properties of the utilized zeolite are listed in Table 1. This experiment was conducted in three replications with three factors. The first factor was natural zeolite with nanopores in five levels including $0,30,60,90$ and $120 \mathrm{~g}$ zeolite / $21000 \mathrm{~g}$ soil (the full capacity of pots was $30 \mathrm{~kg}$ ). The nanopore size of this zeolite was $0-3 \mathrm{~mm}$. The second factor was the lead pollution in two levels including (1) a pollutant-free control, (2) lead in the form of $99 \%$ lead nitrate at the rate of $400 \mathrm{mg}$ lead in one kg dry soil, The third factor was cadmium pollution in two levels including (1) a pollutant-free control (2) cadmium at the rate of $8 \mathrm{mg}$ cadmium in one $\mathrm{kg}$ dry soil. $3 \mathrm{~kg}$ of sand poured into the bottom of each pot for drainage. Irrigation was also conducted from the bottom of the pots.

\section{The second experiment (modified nano zeolite)}

In this phase, the natural nano zeolite was treated with $2 \mathrm{~N}$ nitric acid. Initially, zeolites were washed, oven-dried at $72{ }^{\circ} \mathrm{C}$ oven and placed in $2 \mathrm{~N}$ nitric acid for $20 \mathrm{~h}$. Then they were eluted with distilled water and dried at $72{ }^{\circ} \mathrm{C}$. This zeolite was incorporated with the soil at the required rates prior to cultivation. The specific surface area was measured by the BET method the see Table 2 .

This experiment, like the first one, was conducted in three replications with three factors. The first factor was modified zeolite with nanopore in five levels: 0, 30, 60, 90 and $120 \mathrm{~g}$ zeolite $/ 21,000 \mathrm{~g}$ soil. The second factor was lead in two levels: (1) a pollutant-free control, (2) lead in the form of $99 \%$ lead nitrate at a rate of $400 \mathrm{mg}$ lead in one $\mathrm{kg}$ 
dry soil, The third factor was cadmium: (1) a pollutant-free control (2) cadmium at a rate of $8 \mathrm{mg}$ cadmium in one $\mathrm{kg}$ dry soil.

\section{The third experiment (nanoporous activated carbon)}

This experiment tested nanoporous activated carbon derived from lemon wood. The type of the activated carbon (micro-, meso- or macro-) and its distribution percentage was determined with an electron microscope and its granulation was assessed using an 80 mesh sieve. The activated carbon properties are listed in Table 3. As above, the third experiment also studied the response of Medicago scutellata L. to the treatments in three replications with three factors. The first factor was nanoporous activated carbon at the levels $0,10,20,30$ and $40 \mathrm{~g}$ activated carbon/ $21,000 \mathrm{~g}$ soil. The second factor was lead in (1) a pollutantfree control, (2) in the form of $99 \%$ lead nitrate at the rate of $400 \mathrm{mg}$ lead in one $\mathrm{kg}$ dry soil, The third factor was cadmium in (1) a pollutant-free control (2) at the rate of 8 $\mathrm{mg}$ cadmium in one kg dry soil. The pollutants were added as cadmium chloride $\left[\begin{array}{llll}\mathrm{CdCl}_{2} & 21 / 2 & \mathrm{H}_{2} \mathrm{O}=228.35 \text {, from }\end{array}\right.$ CHEM-LAB Belgium] and $99 \%$ lead nitrate $\left[\mathrm{Pb}\left(\mathrm{NO}_{3}\right)_{2}\right.$ from CHEM-LAB, Belgium]. In a first step, the required amount of each pollutant for $21,000 \mathrm{~g}$ soil was measured. Then, the determined amount was dissolved in $2 \mathrm{~L}$ water and added to the pots from the top side.

\section{Statistical analysis}

Analysis of variance was conducted using SAS, and means were compared according to the Duncan's multiple range test at $\mathrm{P} \leq 0.05$. Curves were drawn using Excel 2007 software.

\section{Results and Discussion}

Lead and cadmium accumulation in plant roots and shoots in response to natural and modified nano zeolite

Application of natural zeolite significantly $(\mathrm{P} \leq 0.01)$ reduced the $\mathrm{Pb}$ and $\mathrm{Cd}$ concentrations in shoots and roots of the plants (Fig.1 a,d and 2a,d). Analysis of variance of the measured traits is given in Tables 4, 5 and 6. For comparisons of means, see also Figs 1, 2 and 3. The lowest $\mathrm{Pb}$ concentration in shoots was achieved with the highest zeolite application. This demonstrates that zeolite is an efficient adsorbent for reducing heavy metal translocation from polluted soils to plant tissue. The highest of $\mathrm{Pb}$ and $\mathrm{Cd}$ contents in plant roots and shoots was related to $\mathrm{Z}_{0} \mathrm{~Pb}_{400} \mathrm{Cd}_{80}$. Comparing zeolite application rates also indicated that the lowest absorption and translocation of $\mathrm{Pb}$ and $\mathrm{Cd}$ to alfalfa roots and shoots was related to $\mathrm{Z}_{120} \mathrm{~Pb}_{400} \mathrm{Cd}_{80}$. Increasing the application rate of zeolite reduced the $\mathrm{Pb}$ and $\mathrm{Cd}$ content in both plant parts; this reduction trend was more evident at 90 and $120 \mathrm{mg}$ zeolite $/ \mathrm{kg}$ soil rates. This decreasing trend of the $\mathrm{Pb}$ and $\mathrm{Cd}$ concentration in alfalfa roots and shoots was also observed in the interaction of $\mathrm{Pb} \times \mathrm{Cd}$; application of higher zeolite rates in treatments containing both $\mathrm{Pb}$ and $\mathrm{Cd}$ resulted in a higher reduction of $\mathrm{Pb}$ and $\mathrm{Cd}$ in both tissues compared with the treatments containing only $\mathrm{Pb}$.

Shi et al. (2009) reported that zeolite fixes heavy metals in soil and prevents them from being absorbed by plants in three stages: First, the dissolved zeolite produces an alkaline environment in the soil, resulting in the deposition of insoluble phases. The newly formed phase contains the heavy metals as the main component. Then, the enhanced alkalinity improves the adsorption of metals by the metalcomplex levels. The surface of minerals has a positive charge at low $\mathrm{pH}$; when the $\mathrm{pH}$ increases, it changes to a negative charge, which increases cation adsorption in stable complexes with negative bases. Mohamadisani et al. (2011) found that zeolites significantly reduced the $\mathrm{Pb}$ content in the shoots of wheat plants cultivated in a medium containing mineral wastes. Shi et al. (2009) also reported that zeolite can significantly reduce $\mathrm{Pb}$ absorption by plants and convert available forms of $\mathrm{Pb}$ to unavailable forms. Mahabadi et al. (2007) conducted an experiment using zeolite as a cadmium adsorbent in the soil and reported that the presence of zeolite in the soil reduced the $\mathrm{Cd}$ content in drainage water. The present evaluation of $\mathrm{Pb}$ and $\mathrm{Cd}$ accumulation in roots and shoots (Fig.1 b,e; Fig.2 b,e) indicated that absorption and translocation to the plant tissues decreased when the application rate of modified zeolite increased: the pollutant concentration were higher in shoots than in roots. This is because lead and leadcontaining compounds have a low solubility in soil and are not easily available to plants, making it is difficult for them to absorb $\mathrm{Pb}$ in their roots and transfer it to their shoots.

Table 1. Chemical analysis of the natural zeolite used in this study

\begin{tabular}{cccccccc}
\hline Component & $\mathrm{SiO}_{2}$ & $\mathrm{Al}_{2} \mathrm{O}_{3}$ & $\mathrm{Fe}_{2} \mathrm{O}_{3}$ & $\mathrm{MgO}$ & $\mathrm{CaO}$ & $\mathrm{Na}_{2} \mathrm{O}$ & $\mathrm{K}_{2} \mathrm{O}$ \\
\hline Content $(\%)$ & 63.74 & 11.7 & 1.65 & 1.18 & 1.83 & 0.51 & 2.44 \\
\hline
\end{tabular}

Table 2. Specific surface area $\left(\mathrm{g} \cdot \mathrm{m}^{-2}\right)$ of three nano adsorbents

\begin{tabular}{ccc}
\hline Nano-porous adsorbent & Natural zeolite & 94 \\
\hline Sample & Modified zeolite & 308 \\
\hline- & Activated carbon & 660 \\
\hline
\end{tabular}

Table 3. Physical properties of the activated carbon

\begin{tabular}{cc}
\hline Moisture content wt $\%$ & $4 \%$ \\
\hline Methylene blue & $6 \%$ \\
Hardness & $95 \%$ \\
Ash content wt $\%$ & $5 \%$ \\
\hline Iodine number & $660 \mathrm{mg} \cdot \mathrm{g}^{-1}$ \\
\hline
\end{tabular}


1188

Accordingly, the $\mathrm{Pb}$ content in roots is usually higher than in shoots. The lowest $\mathrm{Pb}$ and $\mathrm{Cd}$ contents in alfalfa roots and shoots were related to $\mathrm{MZ}_{120} \mathrm{~Pb}_{400} \mathrm{Cd}_{80}$, the highest contents to $\mathrm{MZ}_{0} \mathrm{~Pb}_{400} \mathrm{Cd}_{80}$.

One method to improve the adsorption rate in zeolites is to increase their adsorptive surface by reducing the granulation size. The absorption of nutrients and heavy metals by roots is influenced by the interaction of soil properties and plant factors. Soil properties include $\mathrm{pH}$, salinity, nutrient concentrations, and availability of nutrients to plant roots. In our experiment, treating the natural zeolite (clinoptilolite) with nitric acid increased the efficiency of heavy metal adsorption by altering the moisture content and $\mathrm{Si} / \mathrm{Al}$ ratio in the structure of the zeolite network. The addition of ions with a specific radius into the zeolite network will induce changes in the network gap and structure. Although these changes do not affect the overall structure of zeolite, the replacement of ions in the zeolite structure does cause certain changes in channel size and thus zeolite properties. The result is an enhanced zeolite adsorption rate.

Table 4. Result of Analysis of variance; effect of Pb, Cd and Zeolite on measured traits

\begin{tabular}{|c|c|c|c|c|c|c|c|}
\hline S.O.V & $\mathrm{df}$ & $\begin{array}{c}\mathrm{Pb} \\
\text { concentration } \\
\text { in shoot }\end{array}$ & $\begin{array}{c}\mathrm{Pb} \\
\text { concentration } \\
\text { in root }\end{array}$ & $\begin{array}{c}\mathrm{Pb} \\
\text { concentration } \\
\text { in soil }\end{array}$ & $\begin{array}{c}\text { Cd } \\
\text { concentration } \\
\text { in shoot }\end{array}$ & $\begin{array}{c}\mathrm{Cd} \\
\text { concentration } \\
\text { in root }\end{array}$ & $\begin{array}{c}\mathrm{Cd} \\
\text { concentration } \\
\text { in soil }\end{array}$ \\
\hline $\mathrm{Pb}$ & 1 & $25821.5^{* *}$ & $724150.9^{* *}$ & $22346.69^{* *}$ & $228.1^{* *}$ & $315.9^{* *}$ & $66.42^{* *}$ \\
\hline $\mathrm{Cd}$ & 1 & $270.15^{* *}$ & $0.541^{\mathrm{ns}}$ & $656.5^{* *}$ & $25185.48^{* *}$ & $25623.56^{* *}$ & $2457.98^{* *}$ \\
\hline Zeolite & 4 & $1868.83^{*}$ & $6407.84^{* *}$ & $0.431^{\mathrm{ns}}$ & $427^{* *}$ & $1660.56^{* *}$ & $106.83^{* *}$ \\
\hline $\mathrm{Pb}^{*} \mathrm{Cd}$ & 1 & $0.271^{\mathrm{ns}}$ & $500.83^{*}$ & $656.9^{* *}$ & $228.15^{* *}$ & $0.314^{\mathrm{ns}}$ & $0.623^{\text {ns }}$ \\
\hline $\mathrm{Pb}^{*} \mathrm{Z}$ & 4 & $1871.14^{*}$ & $0.637 \mathrm{~ns}$ & $4300.16^{*}$ & $2.05^{\mathrm{ns}}$ & $25.64^{* *}$ & $0.912^{\text {ns }}$ \\
\hline $\mathrm{Cd}^{*} \mathrm{Z}$ & 4 & $0.42^{\mathrm{ns}}$ & $250.97^{* *}$ & $0.123 \mathrm{~ns}$ & $428.65^{* *}$ & $0.16^{\mathrm{ns}}$ & $106.87^{* *}$ \\
\hline $\mathrm{Z}^{*} \mathrm{~Pb}^{*} \mathrm{Cd}$ & 4 & $41.87^{* *}$ & $251.09^{* *}$ & $125.68^{* *}$ & $2.16^{\mathrm{ns}}$ & $25.68^{* *}$ & $9.0002^{*}$ \\
\hline Error & 40 & 8.02 & 22.6 & 15.4 & 10.2 & 4.56 & 1.6 \\
\hline CV (\%) & 13.6 & 4.32 & 8.7 & 7.5 & 10.32 & 7.4 & \\
\hline
\end{tabular}

Table 5. Result of Analysis of variance; effect of Pb, Cd and Modified Zeolite on measured traits

\begin{tabular}{|c|c|c|c|c|c|c|c|}
\hline S.O.V & $\mathrm{df}$ & $\begin{array}{c}\mathrm{Pb} \\
\text { concentration } \\
\text { in shoot }\end{array}$ & $\begin{array}{c}\mathrm{Pb} \\
\text { concentration } \\
\text { in root }\end{array}$ & $\begin{array}{c}\mathrm{Pb} \\
\text { concentration } \\
\text { in soil }\end{array}$ & $\begin{array}{c}\mathrm{Cd} \\
\text { concentration } \\
\text { in shoot }\end{array}$ & $\begin{array}{c}\mathrm{Cd} \\
\text { concentration } \\
\text { in root }\end{array}$ & $\begin{array}{c}\mathrm{Cd} \\
\text { concentration } \\
\text { in soil }\end{array}$ \\
\hline $\mathrm{Pb}$ & 1 & $32943.51^{* *}$ & $431838.9^{* *}$ & $9.1579 .20^{*}$ & $163.63^{* *}$ & $143.37^{* *}$ & $0.841^{\mathrm{ns}}$ \\
\hline $\mathrm{Cd}$ & 1 & $187.97^{*}$ & $1706.02^{* *}$ & $318.45^{* *}$ & $12039.18^{* *}$ & $0.1384 \mathrm{~ns}$ & $3533.87^{* *}$ \\
\hline Modified Zeolite & 4 & $731.99^{* *}$ & $0.1168^{\mathrm{ns}}$ & $1679.34^{* *}$ & $134.069^{* *}$ & $564.79^{* *}$ & $162.06^{* *}$ \\
\hline $\mathrm{Pb}^{*} \mathrm{Cd}$ & 1 & $187.83^{*}$ & $0.1705^{\mathrm{ns}}$ & $0.312^{\mathrm{ns}}$ & $163.39^{* *}$ & $0.124 \mathrm{~ns}$ & $0.7518^{\mathrm{ns}}$ \\
\hline $\mathrm{Pb}^{*} \mathrm{MZ}$ & 4 & $5.77^{\mathrm{ns}}$ & $1182.95^{*}$ & $1679.2^{* *}$ & $3.66^{\mathrm{ns}}$ & $11.58^{*}$ & $11.68^{* *}$ \\
\hline $\mathrm{Cd}^{*} \mathrm{MZ}$ & 4 & $5.66^{\mathrm{ns}}$ & $311.91^{* *}$ & $0.915^{\mathrm{ns}}$ & $3.76^{\mathrm{ns}}$ & $553.51^{* *}$ & $0.1283^{\text {ns }}$ \\
\hline $\mathrm{MZ}^{*} \mathrm{~Pb}^{*} \mathrm{Cd}$ & 4 & $732.13^{* *}$ & $0.312 .97^{\mathrm{ns}}$ & $318.18^{* *}$ & $134.14^{* *}$ & $10.21^{*}$ & $11.67^{* *}$ \\
\hline Error & 40 & 13.81 & 24.21 & 17.5 & 2.51 & 3.91 & 1.15 \\
\hline $\mathrm{CV}(\%)$ & 7.76 & 5.79 & & & 11.16 & 12.9 & 13.1 \\
\hline
\end{tabular}

Table 6. Result of Analysis of variance; effect of $\mathrm{Pb}, \mathrm{Cd}$ and Activated Carbon (AC) on measured traits

\begin{tabular}{|c|c|c|c|c|c|c|c|}
\hline S.O.V & $\mathrm{df}$ & $\begin{array}{c}\mathrm{Pb} \\
\text { concentration } \\
\text { in shoot }\end{array}$ & $\begin{array}{c}\mathrm{Pb} \\
\text { concentration } \\
\text { in root }\end{array}$ & $\begin{array}{c}\mathrm{Pb} \\
\text { concentration } \\
\text { in soil }\end{array}$ & $\begin{array}{c}\mathrm{Cd} \\
\text { concentration } \\
\text { in shoot }\end{array}$ & $\begin{array}{c}\mathrm{Cd} \\
\text { concentration } \\
\text { in root }\end{array}$ & $\begin{array}{c}\mathrm{Cd} \\
\text { concentration } \\
\text { in soil }\end{array}$ \\
\hline $\mathrm{Pb}$ & 1 & $438.45^{* *}$ & $49265.3^{* *}$ & $447.85^{* *}$ & $11.64^{* *}$ & $119.24^{* *}$ & $66.42^{* *}$ \\
\hline $\mathrm{Cd}$ & 1 & $1.72^{* *}$ & $374.9^{* *}$ & $2385.4^{* *}$ & $1136.65^{* *}$ & $9985.76^{* *}$ & $2457.98^{* *}$ \\
\hline $\begin{array}{c}\text { Activated } \\
\text { Carbon (AC) }\end{array}$ & 4 & $4.96^{* *}$ & $678.55^{* *}$ & $3850.06^{* *}$ & $17.74^{* *}$ & $49.55 \mathrm{~ns}$ & $106^{* *}$ \\
\hline $\mathrm{Pb}^{*} \mathrm{Cd}$ & 1 & $0.035 \mathrm{~ns}$ & $36.2 \mathrm{~ns}$ & $2452.01^{* *}$ & $11.66^{* *}$ & $119.15^{* *}$ & $0.633 \mathrm{~ns}$ \\
\hline $\mathrm{Pb}^{*} \mathrm{AC}$ & 4 & $5.47^{* *}$ & $678.32^{* *}$ & $3916.8^{* *}$ & $6.64^{* *}$ & $5.33^{*}$ & $0.1983 \mathrm{~ns}$ \\
\hline $\mathrm{Cd}^{*} \mathrm{AC}$ & 4 & $0.082 \mathrm{~ns}$ & $4.24 \mathrm{~ns}$ & $68.27 \mathrm{~ns}$ & $6.624^{* *}$ & $499.78^{* *}$ & $0.178 \mathrm{~ns}$ \\
\hline $\mathrm{AC}^{*} \mathrm{~Pb}^{*} \mathrm{Cd}$ & 4 & $1.61^{* *}$ & $421.56^{* *}$ & $68.29 \mathrm{~ns}$ & $0.75 \mathrm{~ns}$ & $5.33^{*}$ & $9^{* *}$ \\
\hline Error & 40 & 0.075 & 18.47 & 0.077 & 0.506 & 1.88 & 1.6 \\
\hline CV (\%) & & 14 & & & 7.73 & 10.61 & 7.4 \\
\hline
\end{tabular}




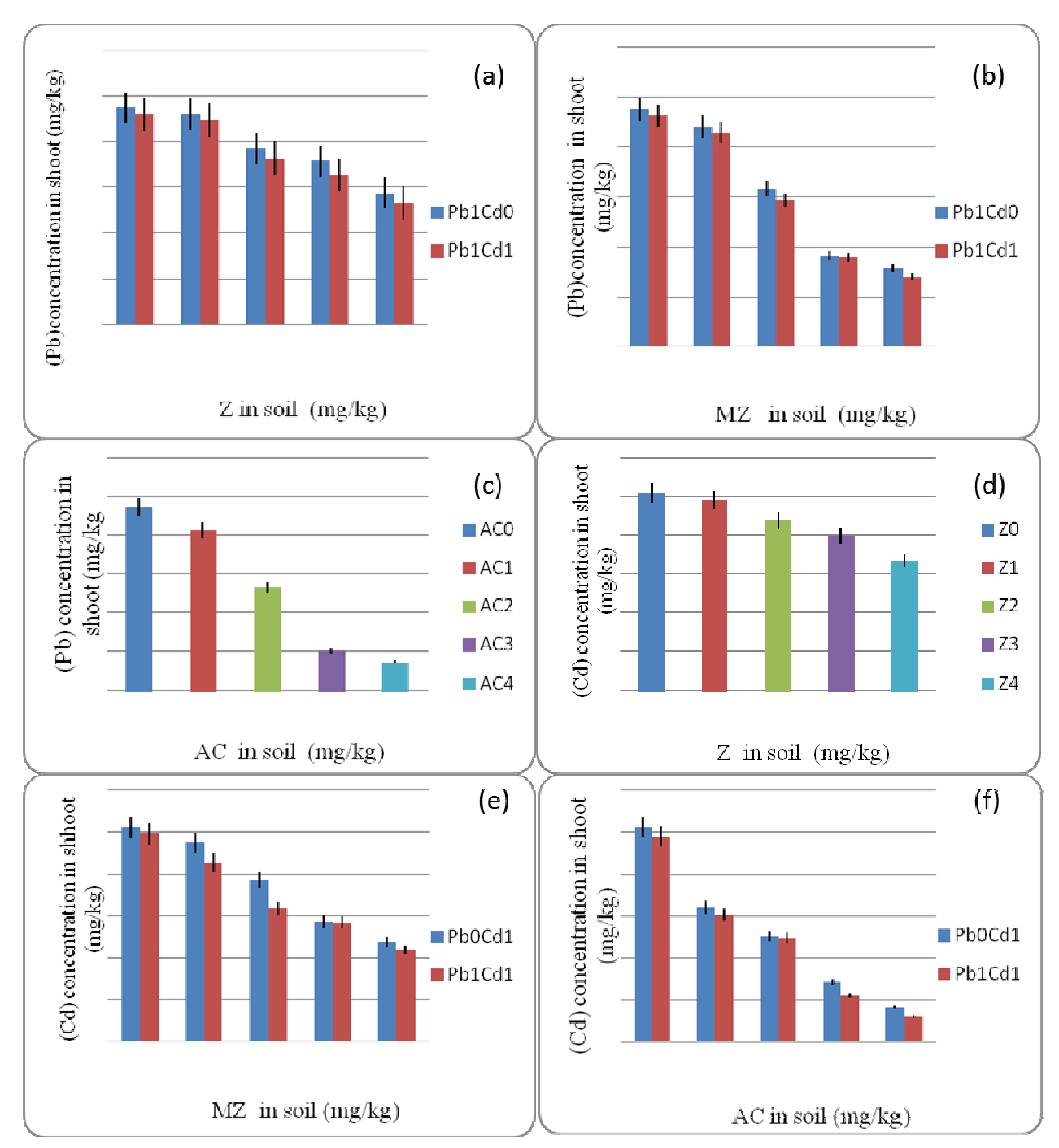

1189

Fig. 1. Mean comparison of the $\mathrm{Z}, \mathrm{MZ}$. AC levels on $\mathrm{Pb}$ and $\mathrm{Cd}$ concentration in shoot of annual alfalfa. a:effects of different $\mathrm{Z}$ levels on $\mathrm{Pb}$ concentration, $\mathrm{b}$ : effects of different $\mathrm{MZ}$ levels on $\mathrm{Pb}$ concentration, $\mathrm{c}$ : effects of different $\mathrm{AC}$ levels on $\mathrm{Pb}$ concentration, $\mathrm{d}$ : effects of different $\mathrm{Z}$ levels on $\mathrm{Cd}$ concentration, e: effects of different MZ levels on Cd concentration, f: effects of different AC levels on Cd concentration, Pb1: lead (400 mg/g), Pb0: without Pb, Cd0 without Cd, Cd1: cadmium (80 $\mathrm{mg} / \mathrm{kg}$ ), Modified zeolite (MZ), Zeolite (Z), Activated carbon (AC). Pb1Cd1: lead (400 mg/kg) and cadmium (80 mg/kg). $\mathrm{AC} 0=0 \mathrm{mg} / \mathrm{kg}, \mathrm{AC} 1=10,000 \mathrm{mg} / \mathrm{kg}, \mathrm{AC} 2=20,000 \mathrm{mg} / \mathrm{kg}, \mathrm{AC} 3=30,000 \mathrm{mg} / \mathrm{kg}, \mathrm{AC} 4=40,000 \mathrm{mg} / \mathrm{kg} . \mathrm{MZ0}=0 \mathrm{mg} / \mathrm{kg}$, $\mathrm{MZ1}=30,000 \mathrm{mg} / \mathrm{kg}, \mathrm{MZ2}=60,000 \mathrm{mg} / \mathrm{kg}, \mathrm{MZ3}=90,000 \mathrm{mg} / \mathrm{kg}, \mathrm{MZ} 4=120,000 \mathrm{mg} / \mathrm{kg} . \mathrm{Z} 0=0 \mathrm{mg} / \mathrm{kg}, \mathrm{Z} 1=30,000 \mathrm{mg} / \mathrm{kg}$, $\mathrm{Z} 2=60,000 \mathrm{mg} / \mathrm{kg}, \mathrm{Z} 3=90,000 \mathrm{mg} / \mathrm{kg}, \mathrm{Z} 4=120,000 \mathrm{mg} / \mathrm{kg}$

Lead and cadmium accumulation in plant roots and shoots in response to nanoporous activated carbon

Applying nanoporous activated carbon significantly $(\mathrm{P} \leq 0.01)$ affected lead and cadmium content in annual alfalfa roots and shoots (Table 6). The lowest contents in both tissues were achieved at the highest activated carbon application rate $\left(\mathrm{AC}_{40,000} \mathrm{mg} / \mathrm{kg}\right)$; the highest $\mathrm{Pb}$ content of in shoots was related to the activated carbon -free treatment $\left(\mathrm{AC}_{0} \mathrm{~Pb}_{400} \mathrm{Cd}_{0}\right)$. (Fig. 1c). The interaction of $\mathrm{Pb}$ and $\mathrm{Cd}$ indicated that they were absorbed the slowest by plant roots when applied together; when activated carbon was applied along with $\mathrm{Pb}$ and $\mathrm{Cd}\left(\mathrm{AC}_{40} \mathrm{~Pb}_{400} \mathrm{Cd}_{80}\right)$, their absorption by plant was even lower (Fig. 2c, Fig. 1f). The highest absorption and translocation of $\mathrm{Pb}$ and $\mathrm{Cd}$ to roots and shoots was related to $\left(\mathrm{AC}_{0} \mathrm{~Pb}_{400} \mathrm{Cd}_{80}\right)$. (Fig.1 c,f; Fig.2 c,f) The activated carbon used in our experiment was obtained from lemon wood and had an average pore size of $0-5 \mathrm{~nm}$, which enables heavy metal absorption and translocation. Lead adsorption in soil follows the Langmuir model and increases when the $\mathrm{pH}$ rises from 3 to 8.5. Blaylock et al. (1997), however, reported that the solubility of lead in soil with $\mathrm{pH}$ ranging from 5.5-7.5 is influenced by phosphate or carbonate sediments. Thus, although plants can naturally absorb lead, the absorption is disturbed due to low availability (Sharma, Dubey, 2005). The results of our experiments indicated that the lead and cadmium contents 
1190

in roots and shoots decreased when higher amounts of activated carbon were applied. Darvish et al. (2012) found that applying activated carbon in soils polluted with $\mathrm{Pb}$ and $\mathrm{Cd}$ reduced their content in spinach roots, stems and leaves. The adsorption capacity of activated carbon depends on the size of the carbon particles; the smaller the size, the higher the adsorption efficiency. Effect of activated carbon on $\mathrm{Pb}$ removal was also reported by several researchers (Dwivedi $e t$ al., 2008; Karnib et al., 2014). Granular activated carbon is also an effective adsorbent for cadmium removal. It is possible to recycle and reuse activated carbon that is fully saturated with cadmium by washing it with $0.1 \mathrm{~N} \mathrm{HNO}_{3}$ and then with $0.1 \mathrm{~N} \mathrm{NaOH}$ (Reed and Arunachalam, 1994).

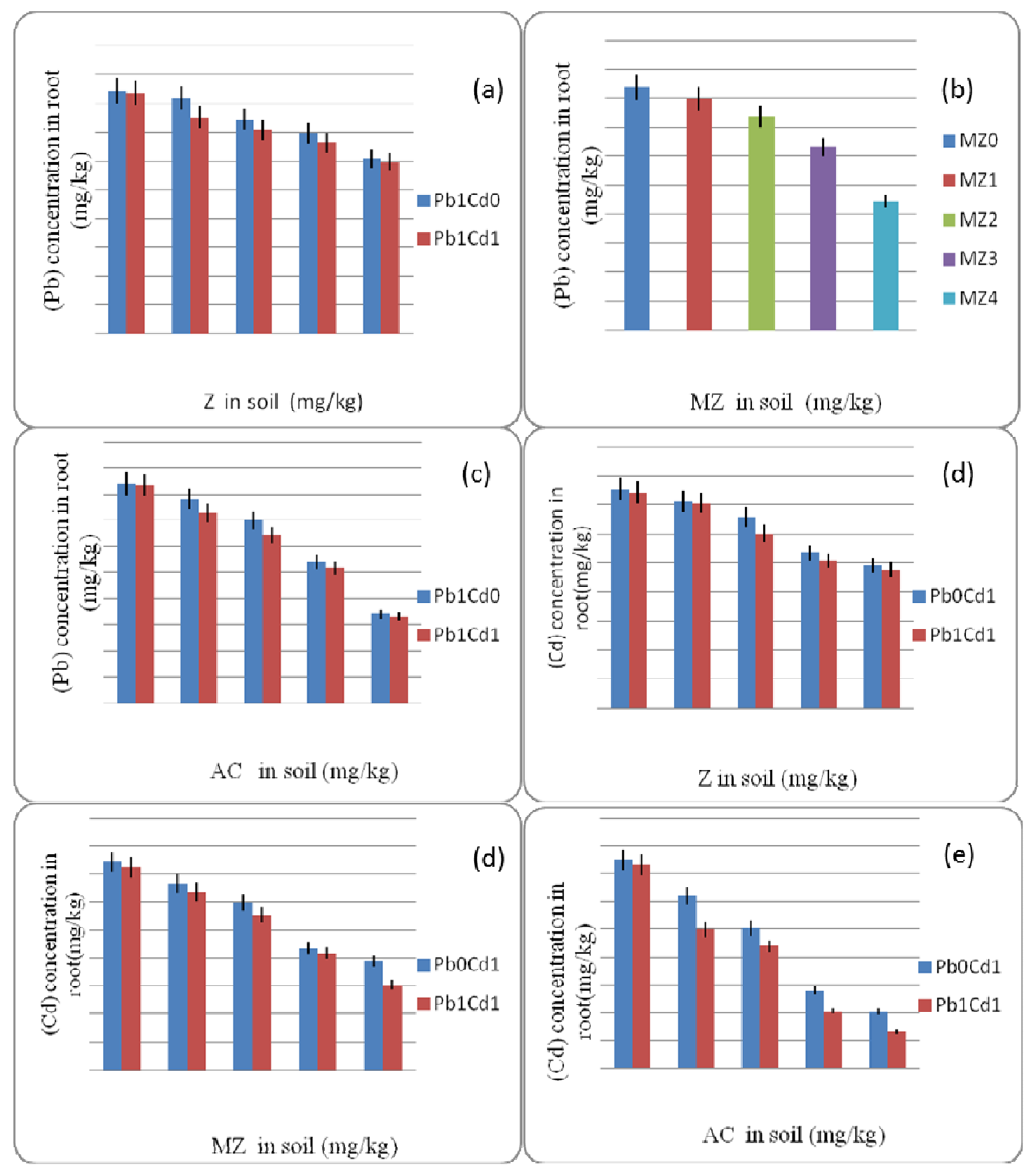

Fig. 2. Mean comparison of the $\mathrm{Z}, \mathrm{MZ}, \mathrm{AC}$ levels on $\mathrm{Pb}$ and $\mathrm{Cd}$ concentration in root of annual alfalfa. a: effects of different $\mathrm{Z}$ levels on $\mathrm{Pb}$ concentration, $\mathbf{b}$ : effects of different $\mathrm{MZ}$ levels on $\mathrm{Pb}$ concentration, $\mathbf{c}$ : effects of different $\mathrm{AC}$ levels on $\mathrm{Pb}$ concentration, $\mathbf{d}$ : effects of different $\mathrm{Z}$ levels on $\mathrm{Cd}$ concentration, e: effects of different $\mathrm{MZ}$ levels on Cd concentration, $\mathbf{f}$ : effects of different AC levels on Cd concentration, Pb1: lead ( $400 \mathrm{mg} / \mathrm{g}$ ), Pb0: without Pb, Cd0 without Cd, Cd1: cadmium (80 $\mathrm{mg} / \mathrm{kg}$ ). Modified zeolite (MZ), Zeolite (Z), Activated carbon (AC). Pb1Cd1: lead (400 mg/kg) and cadmium (80 mg/kg). AC0 $=0 \mathrm{mg} / \mathrm{kg}, \mathrm{AC} 1=10,000 \mathrm{mg} / \mathrm{kg}, \mathrm{AC} 2=20,000 \mathrm{mg} / \mathrm{kg}, \mathrm{AC} 3=30,000 \mathrm{mg} / \mathrm{kg}, \mathrm{AC} 4=40,000 \mathrm{mg} / \mathrm{kg} . \mathrm{Mz} 0=0 \mathrm{mg} / \mathrm{kg}, \mathrm{MZ} 1=$ $30,000 \mathrm{mg} / \mathrm{kg}, \mathrm{MZ2}=60,000 \mathrm{mg} / \mathrm{kg}, \mathrm{MZ} 3=90,000 \mathrm{mg} / \mathrm{kg}, \mathrm{MZ} 4=120,000 \mathrm{mg} / \mathrm{kg} . \mathrm{Z} 0=0 \mathrm{mg} / \mathrm{kg}, \mathrm{Z} 1=30,000 \mathrm{mg} / \mathrm{kg}, \mathrm{Z} 2=$ $60,000 \mathrm{mg} / \mathrm{kg}, \mathrm{Z} 3=90,000 \mathrm{mg} / \mathrm{kg}, \mathrm{Z} 4=120,000 \mathrm{mg} / \mathrm{kg}$ 
1191

Lead and cadmium concentration in soil in response to nanoporous activated carbon, natural zeolite and modified zeolite

Nanoporous activated carbon, natural zeolite and modified zeolite had a significant effect on the lead and cadmium concentration in soil (Tables 4, 5 and 6). Applying higher levels of adsorbents (activated carbon and natural/modified zeolite) reduced the concentration of both metals in the soil and in plant roots and shoots. The application of nano-adsorbents activated carbon significantly $(\mathrm{P} \leq 0.01)$ reduced the $\mathrm{Pb}$ and $\mathrm{Cd}$ content in the soil (Fig. 3); the lowest $\mathrm{Pb}$ content in the soil was related to the highest level (AC40,000 mg/kg), whereas the highest content was related to the activated carbon -free treatment $\left(\mathrm{AC}_{0} \mathrm{~Pb}_{400} \mathrm{Cd}_{80}\right.$; Fig. $\left.3 \mathrm{c}\right)$. The reduction of $\mathrm{Pb}$ and $\mathrm{Cd}$ in the soil demonstrates the role of activated carbon in heavy metal adsorption and their blockage in soil. The large surface area of nanoporous activated carbon, coupled with Van der Waals forces of molecules, adsorbs organic or other types of pollutants in the pores. Depending on the form and size of these pores, activated carbon can easily absorb every type of pollutant. The volume of all pores in each gram of carbon varies from $0.7-1.3 \mathrm{~cm}^{3}$ because of their large number. These numerous nanopores provide an extensive surface area of about $500-700 \mathrm{~m}^{2}$ in each gram of carbon and physically adsorb pollutants. Our results showed that the highest $\mathrm{Pb}$ and $\mathrm{Cd}$ concentration in soil was achieved in $\mathrm{Z}_{0} \mathrm{~Pb}_{400} \mathrm{Cd}_{80}$, the lowest concentration in $\mathrm{Z}_{120} \mathrm{~Pb}_{400} \mathrm{Cd}_{80}$ (Fig. 3a, d). All zeolite treatment levels reduced the $\mathrm{Pb}$ and $\mathrm{Cd}$ concentrations in soil compared with the zeolite-free control. Hamidpoor et al. (2010) studied the mobility and availability of $\mathrm{Pb}$ and $\mathrm{Cd}$ adsorbed on zeolite to plant roots and found that desorption of both metals from the zeolite surface is low. This indicates the ability of zeolite to fix pollutants in soil and block them from being absorbed by roots. The authors reported that desorption from the zeolite surface is a slow process, so that zeolite can effectively protect plants from heavy metal toxicity in polluted soils.

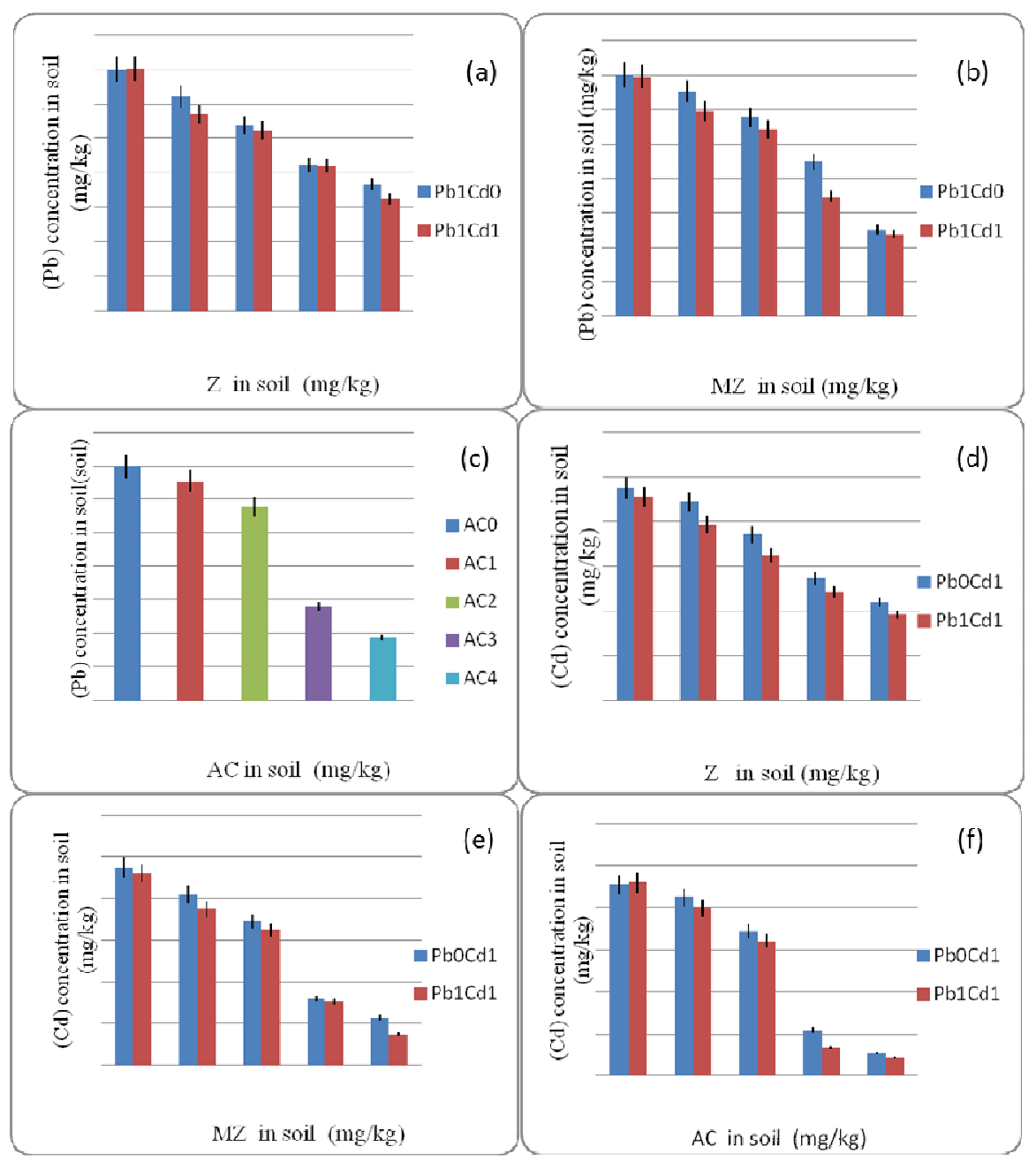

Fig. 3. Mean comparison of the $\mathrm{Z}, \mathrm{MZ}, \mathrm{AC}$, levels on $\mathrm{Pb}$ and $\mathrm{Cd}$ concentration in soil of annual alfalfa. a: effects of different $\mathrm{Z}$ levels on $\mathrm{Pb}$ concentration, $\mathbf{b}$ : effects of different $\mathrm{MZ}$ levels on $\mathrm{Pb}$ concentration, $\mathbf{c}$ : effects of different $\mathrm{AC}$ levels on $\mathrm{Pb}$ concentration, $\mathbf{d}$ : effects of different $\mathrm{Z}$ levels on $\mathrm{Cd}$ concentration, e: effects of different $\mathrm{MZ}$ levels on Cd concentration, $\mathbf{f}$ : effects of different AC levels on Cd concentration, $\mathrm{Pb} 1$ : lead (400 mg/kg). Cd0: without Cd, Cd1: cadmium (80 mg/kg). Modified zeolite (MZ), Zeolite (Z), Activated carbon (AC). Pb1Cd1: lead (400 mg/kg) and cadmium $(80 \mathrm{mg} / \mathrm{kg}) . \mathrm{AC} 0=0$ $\mathrm{mg} / \mathrm{kg}, \mathrm{AC} 1=10,000 \mathrm{mg} / \mathrm{kg}, \mathrm{AC} 2=20,000 \mathrm{mg} / \mathrm{kg}, \mathrm{AC} 3=30,000 \mathrm{mg} / \mathrm{kg}, \mathrm{AC} 4=40,000 \mathrm{mg} / \mathrm{kg} . \mathrm{Mz0}=0 \mathrm{mg} / \mathrm{kg}, \mathrm{MZ1}=$ $30,000 \mathrm{mg} / \mathrm{kg}, \mathrm{MZ2}=60,000 \mathrm{mg} / \mathrm{kg}, \mathrm{MZ3}=90,000 \mathrm{mg} / \mathrm{kg}, \mathrm{MZ} 4=120,000 \mathrm{mg} / \mathrm{kg} . \mathrm{Z} 0=0 \mathrm{mg} / \mathrm{kg}, \mathrm{Z} 1=30,000 \mathrm{mg} / \mathrm{kg}, \mathrm{Z} 2=$ $60,000 \mathrm{mg} / \mathrm{kg} \mathrm{Z3}=90,000 \mathrm{mg} / \mathrm{kg}, \mathrm{Z} 4=120,000 \mathrm{mg} / \mathrm{kg}$ 
1192

Evaluating the effect of modified zeolite on soil $\mathrm{Pb}$ and $\mathrm{Cd}$ concentrations (Fig. 3e,b) showed that the $\mathrm{Pb}$ concentration in soil was the highest in $\mathrm{MZ}_{0} \mathrm{~Pb}_{400} \mathrm{Cd}_{0}$ and lowest in $\mathrm{MZ}_{120} \mathrm{mg} / \mathrm{kg}$. The effect of modified zeolite on blocking $\mathrm{Pb}$ and $\mathrm{Cd}$ in soil was more evident at the 90 and $120 \mathrm{mg} / \mathrm{kg}$ levels. The same trend was observed for cadmium. Studying the interaction of lead and cadmium showed that adding higher rates of modified zeolite along with $\mathrm{Pb}$ and $\mathrm{Cd}$ reduced the metal concentrations in soil more than when applying modified zeolite without $\mathrm{Pb}$ and $\mathrm{Cd}$. Reducing the size of the adsorbent granules increases the surface area/volume ratio which, in turn, enhances the ion exchange sites and the adsorption efficiency. Ok et al. (2007) found that reducing the size of zeolite particles to about $2 \mathrm{~mm}$ significantly increased their capacity to absorb heavy metals.

\section{Conclusions}

Our experiments were designed to increase the internal diameter of pores and channels in natural zeolite and modify the clinoptilolite structure in order to improve its adsorption efficiency. The results show that we reached these objectives. For the first time, modified zeolite was used to remove soil pollutants and block them from being absorbed by plants. We demonstrate that treating natural zeolite (clinoptilolite) with nitric acid altered the zeolite moisture content and the $\mathrm{Si} / \mathrm{Al}$ ratio, increasing zeolite's adsorption efficiency. Mineral acids remove impurities in the zeolite structure. This increases the specific surface area of zeolite, enhancing its adsorption efficiency. In our experiment, all three nano-adsorbents reduced the lead and cadmium concentrations in plant roots and shoots and in the soil. Nonetheless, activated carbon and modified zeolite were more effective than natural zeolite. The best activated carbon application rates were 30 and $40 \mathrm{mg} / \mathrm{kg}$, both of which yielded almost the same results. The best application rate of modified zeolite was $120 \mathrm{mg} / \mathrm{kg}$, which yielded very similar results to $90 \mathrm{mg} / \mathrm{kg}$ in some cases.

\section{Acknowledgements}

The authors appreciate the cooperation and help of the staff of the research farm and the laboratories of the College of Agriculture, Islamic Azad University, Karaj branch, Iran, during these experiments.

\section{Conflict of Interest}

The authors declare that there are no conflicts of interest related to this article.

\section{References}

Ahmad AA, Hameed BH (2010). Fixed-bed adsorption of reactive azo dye onto granular activated carbon prepared from waste. Journal of Hazardous Materials 175(1-3):298-303.

Argiri A, Ioannou Z, Dimirkou A (2013). Impact of new soil amendments on the uptake of lead by crops. Communication in Soil Science and Plant Analysis 44(1-4):566-573.
Benkli YE, Can MF, Turan M, Celik MS (2005). Modification of organozeolite surface for the removal of reactive azo dyes in fixed-bed reactors. Water Research 39(2-3):487-93.

Blaylock MJ, Salt DE, Dushenkov S, Zakharova O, Gussman C, Kapulnik Y, ... Raskin I (1997). Enhanced accumulation of Pb in Indian mustard by soil-applied chelating-agents. Environmental Science and Technology31(3):860-865.

Chen HT, Trewyn BG, Wiench JW, Pruski M, Lin VSY (2010). Urea and thio-urea-functionalized mesoporous silica nanoparticle catalysts with enhanced catalytic activity fordiels-alder reaction. Topics in Catalysis 53(3-4):187-191.

Cocks PS (1992). Plant attributes leading to persistence in grazed annual medics (Medicago spp) growing in rotation with wheat. Australian Journal of Agricultural Research 43(7):1559-1570.

Darvishi S, Ardakani MR, Vazan S, Ghafourian H, Paknejad F, Faregh AH (2012). Feasibility study on reducing lead and cadmium absorption by spinach (Spinacia oleracea L.) in a contaminated soil using nanoporous activated carbon. Journal of Radioanalytical and Nuclear Chemistry 297(1):167-173.

Dwivedi CP, Sahu J, Mohanty C, Mohan BR, Meikap B (2008). Column performance of granular activated carbon packed bed for $\mathrm{Pb}$ (II) removal.Journal of Hazardous Materials 156(1-3):596-603.

Hamidpour M, Afyuni M, Kalbasi M, Khoshgoftarmanesh AA, Inglezakis VJ (2010). Mobility and plant-availability of Cd(II) and Pb adsorbed on zeolite and bentonite. Applied Clay Science 48(3):342-348.

Hoseinzade H, Ardakani M, Shahdi A, Asadi Rahmani H, Noormohammadi G, Miransari M (2016). Rice (Oryza sativa L.) nutrient management using mycorrhizal fungi and endophytic Herbaspirillum seropedicae. Journal of Integrative Agriculture 15(6):1385-1394.

Hu XF, Jiang Y, Shu Y, Hu X, Liu L, Luo F (2014). Effects of mining wastewater discharges on heavy metal pollution and soil enzyme activity of the paddy fields. Journal of Geochemical Exploring 147:139-150.

Kadirvelu K (2005). Activated carbon from industrial solid waste as an adsorbent for the removal of Rhodamine-B from aqueous solution: kinetic and equilibrium studies. Chemosphere 60(8):1009-1017.

Karnib M, Kabbani A, Holail H, Olama Z (2014). Heavy metals removal using activated carbon, silica and silica activated carbon composite. Energy Procedia 50:113-120.

Kayabali K, Kezer H (1998). Testing the ability of Bentonite-amended natural zeolite (Clinoptilolite) to remove heavy metals from liquid waste. Environmental Geology 34(2-3):95-102.

Kocaoba S, Orhan Y, Akyüz T (2007). Kinetics and equilibrium studies of heavy metal ions removal by use of natural zeolite. Desalination 214(13):1-10.

Mahabadi A, Hajabasi MA, Khademi H, Kazemian HH (2007). Soil cadmium stabilization using an Iranian natural zeolite. Geoderma 137(3-4):388-393.

Ok YS, Yang JE, Zhang YS, Kim SJ, Chung DY (2007). Heavy metal adsorption by a formulated zeolite-Portland cements mixture. Journal of Hazardous Materials 147(1-2):91-96.

Panneerselvam P, Thinakaran N, Thiruvenkataravi KV, Palanichamy M, Sivanesan S (2008). Phosphoric acid modified-Y zeolites: A novel, 
efficient and versatile ion exchanger. Journal of Hazardous Materials 159(2-3):427-434.

Panuccio MR, Sorgona A, Rizzo M, Cacco G (2009). Cadmium adsorption on vermiculite, zeolite and pumice: Batch experimental studies. Journal of Environmental Management 90(1):364374.

Putwattana N, Kruatrachue M, Kumsopa A, Pokethitiyook P (2015). Evaluation of organic and inorganic amendments on maize growth and uptake of $\mathrm{cd}$ and $\mathrm{Zn}$ from contaminated paddy soils. International Journal of Phytoremediation 17(2):165-174.

Reed B, Arunachalam S (1994). Removal of lead and cadmium from aqueous waste streams using granular activated carbon. Environmental Progress 13(1):121-131.

Samarbakhsh S, RejaliF, Ardakani MR, Nejad FP, Miransari M(2009). The combined effects of fungicides and arbuscular mycorrhiza on corn ( $Z e a$ mays L.) growth and yield under field conditions. Journal of Biological Sciences 9(4):372-376.
Sharma P, Dubey RS (2005). Lead toxicity in plants. Brazilian Journal of Plant Physiology 17(1):35-52.

Shi WY, Shao HB, Li H, Shao MA, Du S (2009). Progress in the remediation of hazardous heavy metal-polluted soils by natural zeolite. Journal of Hazardous Materials 170(1):1-6.

SongJ (2011). Adsorption characteristics of methylene blue by peanut husk in batch and column modes. Desalination 265(1-3):119-125.

Tratnyek PG, Johnson RL (2006). Nanotechnologies for environmental cleanup. Nano Today 1(2):44 48.

Tsui LS, Roy WR, Cole MA (2002). Removal of dissolved textile dyes from wastewater by compost sorbent. Journal of Color Technology 119(1):14-18.

Wingenfelder U, Nowack B, Furrer G, Schulin R (2005). Adsorption of Pb and Cdbyamine-modified zeolite. Water Research 39(14):3287-3297. 